UDC $342.731(450) ; 322(450)$

CERIF: S140

\author{
Cettina Di Salvo, $\mathrm{PhD}^{*}$
}

\title{
ANTI-DISCRIMINATION LAW ON THE GROUNDS OF RELIGION WITHIN THE ITALIAN LEGAL SYSTEM: SUBSTANTIVE AND PROCEDURAL ASPECTS
}

The author illustrates the normative framework of protection against religious discrimination in Italian legal system, scattered over several different pieces of legislation. The analysis is devoted to the substantive and procedural rules on the principle of equal treatment irrespective of religion. The analysis shows that the law guarantees every aspect of freedom of personal convictions in religious matter and protects not only people who belong to traditional organized religions, but all people who have held religious beliefs or practices. Italian law prohibits discrimination in regard to religion, not just in employment, but also in other areas. Consequently, the scope is wider than the EU Non-discrimination Directive 2000/78/EC, which only covers discrimination in employment, occupation and working conditions. The rules for the procedure before the court, designed to ensure the protection for persons who have been subject to discrimination are then examined. The author focuses in particular on the provisions regarding the legal standing, the burden of proof, and the remedies, which are crucially important for the effective implementation of the principle of equality.

Key words: Right to equal treatment. - Religious discrimination. - Directive 2000/78/EC. - Judicial procedure against discrimination. - Legal standing. - Burden of proof. - Remedies and enforcement.

\section{INTRODUCTION}

The non-discrimination principle requires the equal treatment of an individual or group protected under European law in the fields of public life, employment and other areas, such as the social and economic fields ${ }^{1}$.

* Researcher and Adjunct Professor of Civil Procedure, LUMSA University Department of Law, Palermo, c.disalvo@lumsa.it. The paper is instigated by my lecture 
People should not be treated less favourably than others in similar situations, without reasonable justification, or equally in different situations. Among the various grounds for discrimination covered by the European legislation I will focus on the ground of religion.

As a premise it should be noted that the right to non discrimination and its expansion to different grounds, has taken an increasingly significant role in European law connected to the new perspective of the protection of fundamental rights. The EU Treaties initially, with the narrow view to build an European market, has only provided prohibition of discrimination based on the sex and nationality. Equal treatment of men and women, on matters relating to working conditions, equal pay and working hours, equal treatment of workers irrespective of their nationality, were contemplated to ensure fair competition between the member States and free movement of workers ${ }^{2}$, and not from the perspective of protection of disadvantaged groups. The adoption of the Treaties of Maastricht and Lisbon has marked a new stage in the European Union with regards to fundamental rights, as it provides the accession of the Union to European Convention on Human Rights and recognises the rights, freedoms and principles set out in the Charter of Fundamental Rights of the EU, which have become legally binding and have the same legal value as the Treaties $^{3}$.

given within the Master in European Integration course at University of Belgrade Faculty of Law in March 2016. I am very grateful to the Dean of the Faculty of Law, Prof. Dr. Sima Avramović, to the Head of Master Studies, Prof. Dr. Dragica Vujadinović, and to Prof. Dr. Ivana Kristić, for inviting me to participate in the course "EU Anti-Discrimination Law". I would like to thank all the colleagues at the Faculty of Law in Belgrade for involving me in their academic life.

1 The right of all persons to equality before the law and protection against discrimination constitutes a universal right recognised by the Universal Declaration of $\mathrm{Hu}-$ man Rights, the United Nations Convention on the Elimination of All Forms of Discrimination against Women, United Nations Covenants on Civil and Political Rights and on Economic, Social and Cultural Rights and by the European Convention for the Protection of Human Rights and Fundamental Freedoms, to which all Member States are signatories. Convention No 111 of the International Labour Organisation (ILO) prohibits discrimination in the field of employment and occupation.

2 In this regard, paragraph 1 and 2 of Article 45 of TFEU (ex Article 39 of the Treaty Establishing the European Community, EC Treaty) provides that: "1. Freedom of movement for workers shall be secured within the Union. 2. Such freedom of movement shall entail the abolition of any discrimination based on nationality between workers of the Member States as regards employment, remuneration and other conditions of work and employment", and article 141 (ex Article 119) of TEC which provides the principle of equal pay between men and women for equal work or work of equal value.

3 Paragraph 1 of Article 2 of the Treaty on European Union (TEU) provides that "The Union is based on the values of respect for human dignity, freedom, democracy, equality, the rule of law and respect for human rights, including the rights of persons belonging to minorities"; Article 6 TEU provides that: "The Union recognises the rights, freedoms and principles set out in the Charter of Fundamental Rights of the European 
Within the new context, and given the consideration of the European Court of Human Rights, the principle of non-discrimination has become a crucial element in the European social model and is one of the European Union's basic principles ${ }^{4}$.

In terms of legislation, several Directives have been adopted since 2000 with the aim to combat discriminations, such as Council Directive 2000/43/EC, 2000/78/EC, 2006/54/EC and 2010/41/EC. In particular, the directive 2000/78/EC, of 27 November 2000, in the perspective to put into effect the principle of equal treatment in the Member States, lays down a general framework for combating discrimination in matters of employment and occupation ${ }^{5}$. The Directive protects against direct and indirect discrimination, harassment and victimisation on the ground of religion or belief ${ }^{6}$.

Two aspects need to be made clear first: 1) the directive does not define the terms "religion" or "belief"7 2) religion is taken into consideration as a ground of discrimination just in respect of employment and occupation, unlike the directive on equal treatment between persons irrespective of racial or ethnic origin (2000/43/EC), which is also applied in relation to social security, healthcare, education and access to and supply of goods and services.

Union of [...] 12 December 2007, which shall have the same legal value as the Treaties. 3. Fundamental rights, as guaranteed by the European Convention for the Protection of $\mathrm{Hu}-$ man Rights and Fundamental Freedoms and as they result from the constitutional traditions common to the Member States, shall constitute general principles of the Union's law.".

4 As stated in the Green Paper on Equality and non-discrimination in an enlarged European Union (Text available at http://eur-lex.europa.eu/legal-content/EN/TXT/ HTML/? uri=CELEX:52004DC0379, last visited 20 October 2016.): "the principles of equal treatment and non-discrimination are at the heart of the European Social Model. They represent a cornerstone of the fundamental rights and values that underpin today's European Union".

5 Article 2.1. For the purposes of this Directive, the "principle of equal treatment" shall mean that there shall be no direct or indirect discrimination whatsoever on any of the grounds referred to in Article 1.

6 The other factors of discrimination considered by the Directive 2000/78 are the grounds of age, sex orientation, disability and belief.

7 See in this respect, Rodoljub Etinski, Ivana Krstić, EU Law on the Elimination of Discrimination, Belgrade, 2009, 288; Lucy Vickers, Religion and belief Discrimination in Employment- the Eu law, European Commission, November 2006, 25. About the concept of religion in the law, ex plurimis see: Rafael Palomino Lozano, Religión y derecho comparado, Madrid, 2007, passim. According to the jurisprudence of the European Court of Human Rights (ECtHR), the concept of "religion" in Article 9 of the European Convention on Human Rights is to be interpreted broadly. This Article also protects the right not to observe any religion, see for example the judgment of the European Court of Human Rights of 18 February 1999 in the case of Buscarini and others v. San Marino, no. 24645/94. In this perspective the right to freedom of religion means also freedom of no choice or atheism. 


\section{THE PROHIBITION OF RELIGIOUS DISCRIMINATION IN THE ITALIAN LEGAL SYSTEM: EMPLOYMENT AND OCCUPATION}

The topic of religious discrimination necessarily passes through the freedom of religion, of thought and conscience, which are fundamental rights protected by different international human rights treaties, including UN human rights conventions ${ }^{8}$.

The right to freedom of religion in the Italian legal system is guaranteed by Article 19 of the Republican Constitution of 1948, which provides that "anyone is entitled to freely profess his religious belief in any form, individually or with others, and to promote it and celebrate rites in public or in private, provided they are not offensive to public morality"9. As has been observed, freedom of religion binds the public authorities to observe a position of equidistance and impartiality not only with respect to all religious beliefs (in fact, the public authorities have the duty to protect the confessional minorities and to promote the exercise of moral freedom in conditions of equality ${ }^{10}$ ), but also with respect to all the confessional counter-cultures which require the same consideration and the same respect due to the ideology dominant, provided that they are respectful of human dignity ${ }^{11}$. Furthermore, the right of all persons to equality regardless of their religion before the law constitutes a universal

8 Article 18 of the Universal Declaration; Article 1 and 2 of UN Declaration on the Elimination of All Forms of Intolerance and of Discrimination based on Religion or Belief, adopted in New York on 21 December 1965, ratified in Italy with the law on 13 October, 1975 n. 654.

9 Regarding the principle of equality irrespective of religion, it is also important to emphasize articles 7 and 8 of the Italian Constitution, dedicated to the relation between State and religion, as well as art. 20: "The ecclesiastical character and the purpose of religion or worship of an association or institution may not be a cause for special legislative limitations, nor for special fiscal impositions in its constitution, juridical capacity and any form of activity". See: Alessandro Ferrari, Silvio Ferrari, "Religion and the Secular State: The Italian National Reports to 18th World Congress of Comparative Law", The Cardozo Electronic Law Bulletin, VOL. 16(1), Special Issue, (Ed. P. G. Monateri), Washington 2010; Most recently, Gaetano Silvestri, "La religione nello spazio pubblico. Leggere la costituzione in un'Italia multiculturale", Aggiornamenti sociali, 2015, 196.

10 As it is well known, Italy is a predominantly Catholic country.

11 Vincenzo Pacillo, "Libertà di religione, luoghi di culto e simboli religiosi. Prospettive generali", Veritas et Jus (8), 2004, 87. The autor observes that the exercise of the right to religious freedom "includes - as a corollary logical - two specific rights: the right to use signs and symbols characteristic of own faith and to build places of worship according to the precepts of the confession to which one belongs. These rights can legitimately be compressed when there is the need to protect rights guaranteed by constitutions belonging to individuals or social groups or when there is the need to protect principles, values or interest explicitly mentioned in the Constitution, but only on condition that it is to give rise to a situation of conflict and that such other rights, interests or values would 
right recognised by Article 3 of our Constitution, which provides that: "All citizens have equal social dignity and are equal before the law, without distinction of sex, race, language, religion, political opinions, personal, and social conditions. It is the duty of the Republic to remove those obstacles of an economic and social nature which in fact limit the freedom and equality of citizens, impede the full development of the human person and the effective participation of all workers in the political, economic and social organization of the country".

Religion as a ground for discrimination in Italy was introduced before the adoption of EU Employment Equality Directive 2000/78 (in 2003), in particular in the Law no. 300, 20 May 1970, known as the Statuto dei lavoratori or Workers' Statute, and in the Immigration Law no. 286,25 July $1998^{12}$. Therefore, the regulatory framework regarding discrimination based on religion was present in two legislative bodies, which take into consideration the rules and regulations of principle of equality on the matter of labour and immigration respectively. Workers' Statute, excluding the Constitution which established the basic principles of labour law, is the most important source in matters of work and occupation in Italy's system. In this body of legislation the expression "discriminatory acts" appears for the first time in Italian law ${ }^{13}$.

The Workers' Statute was of considerable importance in implementing the principles of equality laid down in the Italian Constitution as regards employment and occupation; beginning from Article 15, as amended by Article 13, Law 9 d December 1977, n. 903, which provides that any agreement or act is void which intends: a) to subordinate the employment of a worker to the condition that he/she does adhere or does not adhere to a trade association or religion; $b$ ) to dismiss or discriminate an employee in the allocation of qualifications or duties, in transfers, in disciplinary action, or otherwise cause him/her injury because of his/her religion, or belief ${ }^{14}$. Moreover, article 8 of the Statuto states that it is for-

be distorted, or it would be difficult or impossible to exercise if there were no limitation of that fundamental right, and always with reasonable and proportionate measures".

12 Entitled: "Testo unico delle disposizioni concernenti la disciplina dell'immigrazione e norme sulla condizione dello straniero".

13 It should be noted that in the Italian Constitution the term discrimination (or similar) does not appear; unlike Spanish Constitution of 1978, which in Article 14 (Equality) states: "Spaniards are equal before the law, without any discrimination for reasons of birth, race, sex, religion, opinion, or any other personal or social condition or circumstance".

14 Article 15 1. n. 300/1970, recorded under the title "discriminatory act", provides that: "Is null any agreement or act intended to: a) make the employment of a worker subject to the condition that join or not join a trade association or cease to be part of it; $b$ ) dismiss an employee, discriminate him in the allocation of qualifications or duties, in transfers, in disciplinary action, or otherwise cause him injury because of his affiliation or trade union activities or his participation in a strike. The provisions of the preceding para- 
bidden for the employer, for the purpose of recruitment of staff, or during the employment period, to conduct investigations, even through third parties, to discover political opinions, religious or trade union affiliation of the worker ${ }^{15}$; provision which should be integrated with provisions of Italian Personal Data Protection Code ${ }^{16}$. By way of a general remark, questions on religious affiliation or convictions "are incompatible with the secular character of the State which follows a traditional liberal and individualistic approach with respect to religious orientation inquiries"17.

In the Law on immigration (Law no. 286/1998), as mentioned above, there have also been included legislative measures in the area of religious discrimination in workplace. In particular, Article $43^{18}$, in the first paragraph that constitutes discrimination of any behavior which, directly or indirectly, involves a distinction, exclusion, restriction or preference based on religious beliefs and practices (among other ground such as race, color, national or ethnic origin) ${ }^{19}$, and which has the purpose or effect of impairing or nullifying the recognition, enjoyment or exercise, on an equal basis with others, of all human rights and fundamental freedoms in the political, economic, social, cultural, civil or any other field ${ }^{20}$, states, in the second paragraph, that in any case, is discrimination if the em-

graph shall be also applied to discriminatory contracts or acts relating to political, religious, racial, language or sex, handicap, age or sexual orientation or belief".

15 Article 8 (Ban on investigation into employees' opinions) states: "It is prohibited to the employer, for purposes of employment, such as during the course of employment, to conduct investigations, even through third parties, political opinions, religious or trade union of the worker, as well as non-relevant facts to purposes of employees professional qualifications assessment".

16 Legislative decree 30 June 2003, no. 196 "Testo unico delle disposizioni concernenti la disciplina dell'immigrazione e norme sulla condizione dello straniero".

17 A. Ferrari, S. Ferrari, § 1.

18 In Chapter IV entitled "Provisions on social inclusion, on the discrimination and establishment of the fund for migration policies".

19 Paolo Cavana, "Pluralismo religioso e modelli di cittadinanza: L'azione civile contro la discriminazione", Il diritto ecclesiastico, 1/2000, 170, says that the inclusion of religion as a ground of discrimination is an important novelty because, among other things, is the only factor on a voluntary basis that responds to convictions freely embraced by the individual, while the other factors imply strictly biological or historical belonging of an individual to a determined social group, regardless of the personal accession.

20 This is a broader concept compared to that given in the EU Non-discrimination Directives, that does not contain textual reference to unequal treatment. It has been remarked that this definition covers hypotheses of atypical discrimination concerning any human behaviour which has potential effects of discrimination, see: Giuliano Scarselli, "Appunti sulla discriminazione razziale e la sua tutela giurisdizionale", Rivista Diritto Civile, 2001, 807; Gabriele Carapezza Figlia, Divieto di discriminazione e autonomia contrattuale, Napoli, 2013, 37; Paolo Morozzo Della Rocca, "Gli atti discriminatori e lo straniero nel diritto civile", Id, Principio di uguaglianza e divieto di compiere atti discriminatori, Napoli, 2002, 31. 
ployer carries out an act or behaviour which discriminate, directly or indirectly, workers by reason of their religious affiliation, or which adopts a prejudicial treatment resulting from the establishment of criteria which have proportionately a greater disadvantage on workers of a particular religion and does not relate to the essential requirements for the job ${ }^{21}$.

It is to be pointed out that through using the expression religious convictions and practices (Article 43, first paragraph, 286/1998) it is clear that the law guarantees every aspect of freedom of personal convictions in religious matter. The law protects not only people who belong to traditional organized religions such as the Catholic, Ortodox, Jewish or other faiths, but all people who have held religious beliefs or practices. In recruitment policy it means that it is forbidden for an employer to use selection criteria that will cause a distinction or exclusion for the access to the job based on religion, religious opinions, or religious practices. In simple words, employers may not deny employment, training or promotion on the basis of religion conviction. Religion and belief are factors of prohibited differentiation ${ }^{22}$. The ban of discrimination concerns both public and private employers.

Therefore, before the adoption of the Directive 2000/78, the Italian law has already prohibited religious discrimination, as well as racial, national and ethnic discrimination - during the recruitment of the workers and during the ongoing employment period. The right of worker not to be subjected to detrimental treatment because of his/her religion is thus protected.

Finally, in 2003 the Employment Directive 2000/78/EC on equal treatment irrespective of religion and belief (among other grounds as disability, age or sexual orientation) regarding employment and occupation has been implemented in Italy by Legislative decree n. 216 (of 9 July $2003)^{23}$, issued by the government acting upon delegation of the Parliament.

21 Article 43, second paragraph, lett. e). Scarselli, op. ult. cit., notes that the second paragraph, unlike the first, identifies acts or behaviours that have already been identified by the legislator as discriminatory.

22 About the prohibition against religious discrimination in employment relationship, see Vincenzo Pacillo,, Il divieto di discriminazione religiosa nel rapporto di lavoro subordinato, www.olirit, 2004, last visited 20 October 2016.

23 The introduction of the term "belief" implies in the Italian system an extension of workers protection. The Rome Court of Appeal in the interesting Judgment of 19 October 2012 (Fabbrica italiana Pomigliano-Fiom-Cgil nazionale) establishes that trade union affiliation constitutes a belief and notes that "The fact that the term "belief" can be combined with that of "religion" does not mean that belief should be understood that belief, like religion, is characterized by specific characteristics of pervasiveness and stability. In fact, the notion of belief is characterized by a variable application in the different legal sources of the anti-discrimination law, but it certainly includes categories ranging from 
In the light of the implementation of above mentioned Directive, the Italian law covers all areas of employment, including selection criteria and recruitment conditions, promotion, training provisions, benefit provisions, working conditions including dismissals and pay, membership of, and involvement in an organisation of workers or employers, that could be affected by certain discriminatory treatment ${ }^{24}$.

To conclude, in 2012 the Article 18 of Statuto Lavoratori has been amended by 1.28 June 2012, n. 92 , which introduced a new proceedings for discriminatory dismissal ${ }^{25}$, establishing the greatest form of protection represented by the reintegration into work.

\subsection{Discrimination regarding religion - areas apart from employment}

Italian law prohibits discrimination in regard to religion not just in employment, but also in other areas. In fact, under Article 43 of Immigration Act no. 286/1998, the areas covered by the provision are also training, access to house and social services. In particular, it says that it is an act of discrimination if anyone imposes less favourable conditions or refuses to supply goods or services offered to the public to a foreigner only because of his race, religion, ethnicity or nationality; if anyone illegally imposes less favourable conditions or refuses to provide access to employment, housing, education, training and social and welfare services to foreigners legally residing in Italy; if anyone prevents, by actions or omissions, the exercise of economic activity lawfully undertaken by foreigners legally residing in Italy. Thus, we can say that the scope of Article 43 is wider than the implementing legislation of the Directive 2000/78/ $\mathrm{EC}$, which only covers discrimination in employment, occupation and working conditions.

ethics, philosophy, politics (broadly defined) to the sphere of social relations and therefore includes also trade union, to understand as an occasion to express a conception of labor and human dignity in it realized". See: Il laboratorio Fiat. La tutela della Fiom tra diritto sindacale e diritto antidiscriminatorio (Nota a App. Roma, ord. 19 ottobre 2012, App. Potenza 23 marzo 2012 e Trib. Roma, ord. 21 giugno 2012), in Foro italiano, 5, 1716 ss., comment of Mariagrazia Militello, "“Caso Fiat”, affiliazione sindacale e tutela antidiscriminatoria: una lettura fondata sulle fonti internazionali ed europee" (nota a Trib. Roma, ord., 22 gennaio 2013), Argomenti di diritto del lavoro, 2013, 363, with the comment of Valerio De Stefano.

24 Article 3.

25 Most recently, Alberto Lepore, "Non discriminazione, licenziamento discriminatorio ed effettività delle tutele", Riv. giur. lav., 3/2014, 531; Domenico Dalfino, "Il Licenziamento dopo la legge n. 92 del 2012: profili processuali", Il licenziamento individuale nell'interpretazione della legge; Marco De Cristofaro, Gina Gioia, "Il nuovo rito dei licenziamenti: l'anelito della celerità per una tutela sostanziale dimidiata", Ceste, I licenziamenti dopo la legge n. 92 del 2012, 382; Francesco Paolo Luiso, "Il processo speciale per l'impugnazione del licenziamento", Riv. it. Lav. 2013, 125; Alberto Guariso, ll licenziamento discriminatorio, in Giornale di diritto del lavoro e di relazioni industriali, 2014, 351.; Marzia Barbera, "Il licenziamento alla luce del diritto antidiscriminatorio", Riv. giuridica del lavoro e della previdenza sociale, 2013, 139. 


\section{DIRECT AND INDIRECT DISCRIMINATION ON THE GROUND OF RELIGION}

The Italian law, in accordance with the directives on non-discrimination, introduced in 2003 a new definition of discrimination, partially different from that of the above-mentioned national legislation, based on unequal treatment and on the clear distinction between direct and indirect discrimination.

Pursuant to Article 2 of Legislative decree n. 216, direct discrimination occurs where one person is treated less favourably than another, has been or would be treated in a comparable situation because of his/her religion. An example of direct discrimination would be if a Jehovah's Witness job applicant gets passed over for a job in favour of a Catholic applicant who is less suited for the job; or in a call for teachers the preference will be given to those of a certain religion; or staff barred from promotion if they are not of a particular religion ${ }^{26}$.

Indirect discrimination occurs when apparently neutral provision, criterion or practice, would put persons of a certain religion at a particular disadvantage compared to other persons, (unless that provision, criterion or practice is objectively justified by a legitimate aim and the means of achieving that aim are appropriate and necessary). It means that the use of criteria or practices which can have a disparate impact on persons of a particular religion in respect of generality of them are forbidden ${ }^{27}$. An example of indirect discrimination would be if as a seventh day adventists employee needs to take Saturday off work in respect of his religion - for the employer this is not a problem, the employee will make up the time during the

26 In the Case of the Court of Justice C-157/15, request for a preliminary ruling under Article 267 TFEU from the Hof van Cassatie (Court of Cassation), Belgium, the Advocate General Kokott takes the view that there is no direct discrimination on the ground of religion where an employee of Muslim faith is banned from wearing an Islamic headscarf in the workplace, provided that that ban is founded on a general company rule prohibiting visible political, philosophical and religious symbols in the workplace and not on stereotypes or prejudices against one or more particular religions or against religious beliefs in general. If that is the case, there is no less favourable treatment based on religion.

27 European Court of Human Rights in its Judgment of 1 July 2014, S.A.S. v. France, (n. 43835/11) states that the French law of 11 October 2010 prohibiting full veil (known as the niqab or burqa) does not cause a violation of the European Convention of Human Rights and specifically the right to respect for private life, the right to manifestation of religious belief. With reference to the principle of 'non-discrimination', the Strasbourg Court agrees that the French legislative measure, although worded in neutral terms, is likely to deploy injurious effects on the group of Muslim women who want to wear the full veil for religious reasons, that could give rise to an indirect discrimination. For the Court this must be excluded because the French legislative measure responds to an objective and reasonable justification and there is a relationship of proportionality between the means employed and the objectives pursued. 
rest of the week. However, it is discriminative if the employer introduces a new shift pattern, and the adventist employee has to work on Saturday without valid business reason. Harassment shall also be considered discrimination (for example, bullying at work because of the religion).

The assessment as to whether there is a discrimination based on religion or belief requires a comparative judgment between differential treatments. The comparative judgment can also be purely hypothetical, as may be inferred from the literal formulation of the definition itself of direct discrimination.

The reasons behind the act which constitutes discrimination are irrelevant; it means there is discrimination regardless of the intention of the perpetrator of that. In our legal system it is now captured an objective concept of discrimination (both direct and indirect) that attaches decisive significance to the result of actions ${ }^{28}$.

The difference of treatment may be justified where a characteristic related to religion or belief constitutes a genuine occupational requirement, when the objective is legitimate and the requirement is proportionate. Difference which is based on profession of a particular religion or certain beliefs that are practiced as part of religious bodies or other public or private organizations, shall not constitute discrimination where, by reason of the nature of the occupational activities, the religion or belief constitute an essential, legitimate and justified occupational requirements for carrying out of activities ${ }^{29}$. It should also be mentioned that in case of dismissal of a worker by a religious leanings organisations (organizzazioni di tendenza) $)^{30}$ the Italian law does not provide reintegration into the workplace, as required by Article 18 of the Workers' Statute in case of discriminatory dismissal. It means that the unfairly dismissed employee can only claim compensation for the loss, but not the right to be taken back to work. The aim is to prevent forcing of these organizations to retain in work an employee who does not share, or whose orientation is in contrast with their ideological orientation and the aims that they pursue ${ }^{31}$.

28 See the ordinance of Tribunale Alessandria sez. lav. 25 May 2015 n. 1725.

29 See Article 3, par. 5, d.lgs. 216/2003, in line with the 24th recital of the preamble to the Directive 2000/78 "The European Union in its Declaration No 11 on the status of churches and non-confessional organisations, annexed to the Final Act of the Amsterdam Treaty, has explicitly recognised that it respects and does not prejudice the status under national law of churches and religious associations or communities in the Member States and that it equally respects the status of philosophical and non-confessional organisations. With this in view, Member States may maintain or lay down specific provisions on genuine, legitimate and justified occupational requirements which might be required for carrying out an occupational activity.

30 This expression refers to institutions, associations, organizations, etc., pursuing an aim of religious character.

31 According to Italian jurisprudence of the Court of Cassation (Cass. lav. n. 4983/2014) the exemption provision to the rules on unfair dismissal concerning leanings 


\section{JUDICIAL PROCEDURE FOR ENFORCING THE RIGHT TO EQUAL TREATMENT}

The Italian legislator, in order to combat acts of discrimination for racial, ethnic, national or religious reasons, both on the part of public authorities or private, has already in Article 44 of Law on immigration (no. 286/1998) provided a specific procedure before the Court to ask the cessation of the discriminatory conduct (Azione civile contro la discriminazione). This action was the procedural model of reference for the subsequent anti-discrimination legislation of Community origin.

In 2011 with the adoption of the Legislative Decree no. 150 of September 1st $2011^{32}$ (containing the reduction and simplification of civil proceedings) the legal proceedings about discrimination was reformed ${ }^{33}$. From this reform, the civil action against discrimination shall be conducted, according to Article 28 of said Legislative decree, under the simplified and accelerated procedure of the "summary proceedings" (procedimento sommario di cognizione). As provided in Article 28, anyone who believes he or she is a victim of discrimination can apply directly at first instance, namely without a lawyer, to the judge of a Civil Court with territorial jurisdiction in order to obtain an injunction against the discriminatory activity as well as damages. It is possible to make discrimination claim in the tribunal even if the relationship in which the discrimination has occurred has ended ${ }^{34}$. The hearing, in accordance with Article 702 ter of the Italian Civil Procedure Code, takes place avoiding all unnecessary formality, and the judge can choose the most suitable method for gathering evidence.

It should however be said that, although in our legal system exists a specific procedure to fight against discrimination, its effectiveness is

organisation (art. 4 of Law 5 November 1990, n. 108), can only be applied if the employer is a non-entrepreneur employer, or that performs business without typical requirements that characterize, under the law, the figure of the entrepreneur, such as: professionalism, organization, productive activity of goods and services. Also, it should be non-profit organization.

32 Published in the Official Gazette (Gazzetta Ufficiale, 21. 9. 2011, no. 220).

33 The proceedings for discrimination cases, amended in 2011 by Article 28 of legislative Decree 150/2011 contains a reference to all Italian laws covering different grounds of discrimination, except on ground of gender. See: Cettina Di Salvo, "Discriminazione", Riordino e semplificazione dei procedimenti civili, (a cura di Fabio Santangeli), Milano, 2012, 848.

34 In this respect see Article 9 parag. 1 of Directive 2000/78/EC, which reads that: "Member States shall ensure that judicial and/or administrative procedures, including where they deem it appropriate conciliation procedures, for the enforcement of obligations under this Directive are available to all persons who consider themselves wronged by failure to apply the principle of equal treatment to them, even after the relationship in which the discrimination is alleged to have occurred has ended after the relationship in which the discrimination is alleged to have occurred has ended.". 
highly dubious in term of the length of process and effectiveness and of judicial protection for a particularly sensitive area such as discrimination $^{35}$. Moreover, as a result of the recent legislative intervention, the current regulatory framework appears rather complex. The procedural regulation is, in fact, distributed over the following legislative texts: Code of Civil Procedure, Article 28 Legislative Decree 150/2011, Article 18 Workers' Statute for discriminatory dismissal ${ }^{36}$, implementing laws of EU directives, Article 44, Legislative Decree 286/98; which do not facilitate the access of the victims of discrimination to justice.

Instead, it is of importance the establishment of a solidarity fund for administrative or judicial proceedings of the victims of discrimination by the National Bar Council and National Anti-Racial Discrimination Office (UNAR). The Fund operates through a mechanism of anticipation and refund of legal fees, in order to facilitate access to justice for the victims, if they do not have the conditions for granting legal aid.

With specific reference to the use of the civil action in case of discrimination for religious reasons, it has been observed critically that the legislator with the provision of a judicial instrument ad hoc, which, on the one side, entails the subjection to procedure of a sphere of social relations that regards the cultural and religious identity of persons and entire communities and, on the other, removes responsibility from the public authorities in the management of potential social and cultural conflicts requiring specific support measures for the integration. The judicial response to these problems, although it is not a policy, thus without a planning approach but casual and episodic, depending on individual evaluation of the judges of merit, does not favour the necessary cultural and inter-confessional mediation ${ }^{37}$.

\section{LEGAL STANDING}

Any person that believes he/she has been subject to harassment or discriminated against because of their religion can take a legal action before the Court. They can act on their own or through a legal representation. Under Italian law the local representation of the main representative organizations at the national level, which have a legitimate interest in ensuring that the principle of equality, are entitled to act in the name and on behalf or in support of the victim of discrimination, against the author of the act or behavior discriminatory (art. 5 d.lgs. 216/2003) $)^{38}$. Therefore,

35 C. Di Salvo, 843.

36 As amended by Law 28 June 2012, n. 92 (Fornero Reform).

37 In this sense P. Cavana, 185-187.

38 In compliance with Article 9, par. 2 of Directive 2000/78/EC which states that "Member States shall ensure that associations, organisations or other legal entities which 
the Italian law provides two different types of assistance in the judial procedure:

1) Legal entities may engage in civil proceedings for the enforcement of principle of equality, in the name on behalf of victim, against the alleged perpetrator of discrimination. In such cases, they must be authorized from the presumed victim with public act or private deed.

2) Legal entities may also participate and support the victim in the proceedings. It means that the organisations can intervene in proceedings already initiated from the victim (due to the alleged violation of the principle of equality) as a third part to advance the interest of victim. The cessation of discriminatory act or behaviour is in their interest because the purpose of the organization/association is to promote and to protect the principle of equality with reference to factors (under law) which can be a source of discrimination ${ }^{39}$. The Court will decide to allow or not to allow the intervention.

These subjects empowered to take legal action on behalf or in support of the victim shall also be entitled (without permission) when the discrimination in employment and occupation ${ }^{40}$ concerns a group of people $^{41}$ and the members are not identified in a direct and immediate way ${ }^{42}$. For example, an employer declares that he never engages workers of a certain religion. The victims are not identified in direct way, but there is discrimination because the effect is the dissuasion to present the candidacy for a job in his office. This declaration constitutes a form of direct discrimination.

Among the legal entities, which have a legitimate interest in ensuring that the principle of treatment irrespective of religion is applied (Article 5.2, 216/2003), I believe, might be included the representatives of the religious communities to which the discriminated groups belong, such as the Jewish community, the Evangelic-Lutheran community or the Catholic diocese.

have, in accordance with the criteria laid down by their national law, a legitimate interest in ensuring that the provisions of this Directive are complied with, may engage, either on behalf or in support of the complainant, with his or her approval, in any judicial and/or administrative procedure provided for the enforcement of obligations under this Directive".

39 See Article 105, par. 2 of Italian Civil Procedure Code.

40 This rules applies only in the field of employment and occupation, not for the other fields of religious discrimination.

41 The same procedural mechanism works in the field of consumer protection. The Italian Consumer Code (Legislative Decree 6 September 2005 n. 206) allows most representative consumer associations at national level to bring claims, even where a victim cannot be identified. See Cettina Di Salvo, "Sulla legittimazione all'azione collettiva inibitoria: associazioni rappresentative dei consumatori, singolo consumatore e altri organismi”, www.diritto.it, June $30^{\text {th }}, 2011$.

42 Article 5, par. 2, Legislative Decree 216/2003. 
Finally, it should be noted that wide legal standing is a key element in guaranteeing the effectiveness of the principle of non discrimination, because these legal entities can contribute to protect the right to equality. People discriminated often do not want to take legal action for reasons of money (victims have to bear the cost of litigation), because of the weak position of the discriminated or negative consequences in an employment relationship. This type of considerations could lead the victims to renounce to bring the cases to Court, with a very clear consequence of such a decision: the perpetrator of that discrimination can continue to behave in discriminatory way ${ }^{43}$. In addition to that, sometimes the victims are unaware of their rights.

\section{BURDEN OF PROOF}

The general rule concerning the burden of prooving a fact in Italian civil or labour law proceedings is related to the rule concerning the burden of alleging that fact. The party who alleges the fact on which the right is based has to prove it. Therefore, the burden of proof falls on the party advancing the matter in question ${ }^{44}$.

43 With reference to the grounds of sex orientation recently there has been an interesting Italian Case Law, see Tribunal of Bergamo, 06 August 2014 - Court of Appeal of Brescia, 11 December 2014, with comment of Maura Ranieri, "Da Philadelphia a Taormina: dichiarazioni omofobiche e tutela antidiscriminatoria", Riv. It. Dir. Lav. 2015, 125. In 2013, during an interview made in a radio program, a famous Italian criminal lawyer had declared that he would never engaged a homosexual in his office, and specifying that he makes "proper sorting in a way to make sure that this does not happen". Therefore, the association "Advocacy for LGBTI rights" had sued the lawyer for discrimination, and won both, first instance and the appeal proceedings, brought by the losing lawyer. In the view of the Brescia Court, the appellant expressed, publicly, a discriminatory recruitment policy. They are statements which can dissuade candidates, belonging to the category of persons, from submitting their candidacy to his law firm Studio. That certainly impedes access to employment or makes it more difficult. The orders of Italian Court are in line with the case-law of the Court of Justice, Centrum voor gelijkheid van kansen en voor racismebestrijding vs Firma Feryn NV, C. 54/07.

44 The burden of proof is governed by article 2697 of the Italian Civil Code, according to a person who wants to assert its rights in a trial - the facts which constitute the basis of its act must be proved; any person who challenges the rellevance of these facts, or who claims that the right has either been changed or expired, must prove the facts on which the exception is based. The Italian rule is based on Article 1315 of the French Civil Code, the current text of which is "Celui qui réclame l'exécution d'une obligation doit la prouver. Réciproquement, celui qui se prétend libéré doit justifier le paiement ou le fait qui a produit l'extinction de son obligation". With regard to the burden of proof in Italian legal system, ex plurimis Giovanni Verde, L'onere della prova nel processo civile, Napoli, 1974; Gian Antonio Micheli, L'onere della prova, Padova, 1966; Paolo Comoglio, Le prove civili, Torino, 2010, 3rd ed., 293; Michele Taruffo, "La valutazione delle prove", La prova nel processo civile (a cura M. Taruffo), Milano, 2012, 244. 
In order to achieve the aim of ensuring the effective enforcement of principle of equal treatment, the non-discrimination Directives have introduced a specific rule concerning the burden of proof ${ }^{45}$. The paragraph 1 of Article 10 of Directive 2000/78/EC provide that Member States have to take necesarry measures to ensure that, when persons claiming to be a victim of discrimination can establish, before a court or other competent authority, facts from which it may be presumed that there has been direct or indirect discrimination, it is for the respondent to prove that there has been no breach of the principle of equal treatment ${ }^{46}$. This rule ${ }^{47}$, closely connected to the enforcement of the principles of equal treatment, is a response to the need to strengthen the protection of persons that have suffered discrimination who find it more difficult to obtain the evidence necessary to prove the case ${ }^{48}$. The defendant, in fact, often is in a procedural stronger position, especially if it is an employer, because he has a monopoly of the information and he can usually rely on the reluctance of witnesses.

In accordance with the rule laid down in said Directive, the Italian Law provides a procedural facilitation for the claimant who states only certain elements from it - it may be presumed that a discriminatory situation has occurred ${ }^{49}$. The alleged author of discrimination must prove that there was no violation of the principle of non discrimination, other-

45 It is to be noted that the fifteenth recital of the preamble to the Directive 2000/43 states that "The appreciation of the facts from which it may be inferred that there has been discrimination is a matter for national judicial or other competent bodies, in accordance with rules of national law or practice. Such rules may provide in particular for indirect discrimination to be established by any means including on the basis of statistical evidence".

46 The wording of these Articles are based on that of Articles 3 and 4 of the Council Directive 97/80/EC on the burden of proof in cases of discrimination based on sex. On the proof of discrimination in the EU directives see Guillermo Ormazabal Sánchez, Discriminación y carga de la prueba en el proceso civil, Madrid, 2011, 77.

47 This rule is not applied to proceedings in which it is for the court or other competent national body to investigate the facts.

48 See the report by Lilla Farkas, "Reversing the burden of proof: Practical dilemmas at European and national level", 2014, available at http://www.migpolgroup.com/ portfolio/reversing-the-burden-of-proof-practical-dilemmas-at-theeuropean-and-nationallevels, last visited 20 October 2016.

49 With reference to the burden of proof, Article 28(5) d.lgs. 150/2011 states that "Quando il ricorrente fornisce elementi di fatto, desunti anche da dati di carattere statistico, dai quali si può presumere l'esistenza di atti, patti o comportamenti discriminatori, spetta al convenuto l'onere di provare l'insussistenza della discriminazione. I dati di carattere statistico possono essere relativi anche alle assunzioni, ai regimi contributivi, all'assegnazione delle mansioni e qualifiche, ai trasferimenti, alla progressione in carriera e ai licenziamenti dell'azienda interessata". In the early stages of EU directives implementation in Italy the rules on the burden of proof have been incorrectly transposed. On the burden of proof relating to discriminatory dismissal, Domenico Borghesi, "L'onere della prova nei licenziamenti disciplinari e discriminatori", www.judicium.it., last visited 20 June 2016. 
wise he will be liable for a breach of non-discrimination law. This means that in proving his defence, he has to reboot the presumption by showing contrary proof or giving objective reasons for the different treatment ${ }^{50}$.

It is important to emphasise that the shift in the burden of proof to the defendant does not translate in a full exemption of proof for the person who believes he/she is a victim of unequal treatment. The claimant, in fact, has to prove the factual evidence from which an unjustified differential treatment than that alleged may be presumed.

\section{REMEDIES AND SANCTIONS}

According to Article 28 d.lgs. 150/2011, a judge, once he/she has ascertained the religious discrimination, may issue an order to terminate the ongoing discriminatory behaviour or act; an order to rectify the consequences of the discrimination; an order to adopt a plan to rectify the discrimination within a fixed time determined by the Court. It should be noted that the order to cease the unlawful conduct does not constitute a necessary content of the judicial decision, because it is related to the ongoing discrimination. However, if the discrimination happened, the order for cessation can also be justified where the conduct has ongoing consequences, or if there are circumstances that suggest its recurrence. For example if the employer re-grades the work of an employee resulting in a reduction in pay, and the employee believes this is because his/her religion; as a consequence the employee receives less pay.

The Court may order the publication of the decisions, at the expense of the defendant, in a daily national newspaper. The victim of discrimination is also entitled to recover damages to compensate for nonmaterial loss suffered ${ }^{51}$. It represents one of certain cases provided by the

50 The Court of Justice of the European Union, through request for a preliminary ruling under Article 267 TFEU, has provided relevant judgments relating to the burden of proof; see Centrum voor gelijkheid van kansen en voor racismebestrijding contro Firma Feryn NV, C. 54/07. The Court of Luxembourg stated that public statement by an employer, who declares that he will not recruit employees of a certain ethnic or racial origin, may constitute a presumption of existence of discriminatory recruitment policy. The Court observes that, in accordance with EU provisions, the employer has to adduce as evidence to the contrary that it has not breached the principle of equal treatment, which it can do, inter alia, by showing that the actual recruitment practice of the undertaking does not correspond to the statement. See also, Bundesarbeitsgericht (Germany) lodged on 20 August 2010 - Galina Meister v Speech Design Carrier Systems C-415/10; Kelly v National University of Ireland (C-104/10) Asociaţia ACCEPT contro Consiliul Naţional pentru Combaterea Discriminării (C-81/12). Italian Case Law, Cassazione civile, sez. lav., 11/03/2014, n. 5581 .

51 In accordance with the principle that breaches of the non-discrimination Directive must be met with effective proportionate and dissuasive sanctions, which may include 
law of compensation for non-material damage (Article 2059 of the Italian Civil Code) $)^{52}$.

For the purposes of assessment of damages, the court shall take into account the fact that the act or the discriminatory behavior constitutes retaliation to an previous legal action or unjust reaction to a previous activity of the injured party aimed at enforcing compliance with the principle of equal treatment.

Considering that the perpetrator of the discrimination is obliged to perform an act which cannot be performed by third parties, there is a problem of its enforcement in case that he/she does not abide to the judgment. For the purpose of inducing the perpretator to perform a specific act or behaviour, general measure of indirect coercion may be used. In Article 614 bis Civil Procedure Code, with regard to the obligation to perform a specific fungible or infungible act and to the obligation to deliver goods, the Italian law says that the Court must also order, at the initiative of a party, the payment of a fine in favour of the creditor. The judge fixes the amount of money due by the obligor for any violation, or any succeeding non-compliance, or for any delay in the measure.

However, under article 614 bis indirect coercive measures to disputes regarding subordinate employment contract may not be used, as well as to contract for continuative and coordinated services ${ }^{53}$. It means that in case a person was subject to unlawful religious discrimination (incl. age, sex orientation, disability...etc), in relation to conditions for access to employment, vocational training or working conditions, regarding both the public and private sectors, this measure can not be applied, creating a lack of protection.

\section{CONCLUDING REMARKS}

Religious discrimination is undoubtedly a complex phenomenon, which has negative impacts on both, the individual and social levels. Although Italy is predominantly Roman Catholic country, it is officially secular State which guarantees religious freedom and the right of all persons to equality, regardless of their religion - a fundamental right recog-

compensation being paid to the victim. Member States should provide for effective, proportionate and dissuasive sanctions in case of breaches of the obligations under this Directive.

52 G. Carapezza Figlia, 276; Pietro Virgadamo, Danno non patrimoniale e "ingiustizia conformata", Torino, 2014, passim.

53 On the exclusion of employment relationship, among other, see: Giorgio Costantino, "Tutela di condanna e misure coercitive”, Giurisprudenza Italiana, 2014, 737; Michele Taruffo, Note sull'esecuzione degli obblighi di fare e di non fare, in Giurisprudenza Italiana, 2014, 744. 
nised by the Constitution. Religion as a ground for discrimination appears in the legal system of Italy in 1977 in the Workers' Statute, and then in 1998 in the Immigration Law, namely before the Employment Equality Directive 2000/78/EC, which contanined religion as a factor of discrimination.

The effective protection from discrimination on the grounds of religion requires, first of all, a clear, coherent and comprehensive legislative discipline both on the substantive and procedural plan. Although domestic laws provide a wide concept of religious discrimination and prohibit different treatment on grounds of a person's religion in the field of employment and in other fields, and also contain elements to be praised, such as the legal aid, the shift of the burden of proof, the measures that can be taken against both, privates and public administration, it can not be underestimated that regulations are spread across several pieces of legislation. This with specific reference to the procedural rules relating to the civil action, could cause confusion or to mislead the persons who have been subject to discrimination and might make access to justice more difficult. Furthermore, if the religious discriminatory behaviour is e.g. a dismissal, the proceedings against the employer shall be subject to the different rules of Article 18 of the worker's Statute, posed in 2012 by the "Fornero" Reform; discipline which provides nothing about the regime of burden of proof. Similarly, nothing is said about the legal standing before a court of representative entities or other entities. In addition, there is other critical element that can reduce the level of protection in case of unfavourable treatment related to religion - it is concerned with, beyond employment, the lack of provision to allow representative associations or religious communities to bring claims, where victims can not be identified.

To conclude, even if the Italian legislator has foreseen a special procedure against discrimination, the choice of the model of the "summary proceedings", beyond critical comment for choosing it, does not appear capable of guaranteeing the judicial decision within a reasonable time in case of infringement of the principle of equality between persons irrespective of religion. In order to ensure the effective protection against any discrimination, the Italian legislator should work on the reorganization, coordination and harmonisation of substantive and procedural rules through a single legislative act which will replace the existing legal texts. 


\section{REFERENCES}

Barbera, M., "Il licenziamento alla luce del diritto antidiscriminatorio", Rivista giuridica del lavoro e della previdenza sociale, 1/2013.

Borghesi, D., "L'onere della prova nei licenziamenti disciplinari e discriminatori", http://www.judicium.it/saggi_leggi.php?id=682.

Carapezza Figlia, G., Divieto di discriminazione e autonomia contrattuale, (Edizioni Scientifiche Italiane) Napoli, 2013.

Cavana, P., "Pluralismo religioso e modelli di cittadinanza: L'azione civile contro la discriminazione", Il diritto ecclesiastico, 1/2000.

Comoglio, P., Le prove civili, (ed. Utet) Torino, $2010^{3}$.

Costantino, G., "Tutela di condanna e misure coercitive", Giurisprudenza Italiana, 3/2014.

Dalfino, D., "Il Licenziamento dopo la legge n. 92 del 2012: profili processuali", Il licenziamento individuale nell'interpretazione della legge Fornero, (ed. Cacucci), Bari, 2013.

De Cristofaro, M., Gioia G., "Il nuovo rito dei licenziamenti: l'anelito della celerità per una tutela sostanziale dimidiate", http://www.judicium. it/admin/saggi/395/M.\%20De\%20Cristofaro\%20G.\%20Gioia.pdf.

De Stefano, V., “ "Caso Fiat", affiliazione sindacale e tutela antidiscriminatoria: una lettura fondata sulle fonti internazionali ed europee (nota a Trib. Roma, ord., 22 gennaio 2013)", Argomenti di diritto del lavoro, 2/2013.

Di Salvo, C., "Discriminazione", Riordino e semplificazione dei procedimenti civili, (a cura di) Santangeli F., (Ed. Giuffrè), Milano, 2012.

Di Salvo, C., "Sulla legittimazione all'azione collettiva inibitoria: associazioni rappresentative dei consumatori, singolo consumatore e altri organismi", http://www.diritto.it/docs/31901-sulla-legittimazi.

Etinski, R., Krstiæ, I., EU Law on the Elimination of Discrimination, (Pogestei Edition) Belgrade, 2009.

Farkas, L., "Reversing the burden of proof: Practical dilemmas at European and national level", 2014, http://www.migpolgroup.com/portfolio/reversing-the-burden-of-proof-practical-dilemmas-at-theeuropean-and-national-levels.

Ferrari, A., Ferrari. S., "Religion and the Secular State: The Italian National Reports to 18th World Congress of Comparative Law", The Cardozo Electronic Law Bulletin, VOL. 16(1), Special Issue, (Ed. P. G. Monateri), Washington 2010.

Guariso, A., "ll licenziamento discriminatorio", Giornale di diritto del lavoro e di relazioni industriali, 2/2014. 
Lepore, A., "Non discriminazione, licenziamento discriminatorio ed effettività delle tutele", Rivista giuridica del lavoro e della previdenza sociale, $3 / 2014$.

Luiso, F.P., "Il processo speciale per l'impugnazione del licenziamento", Rivista italiana di diritto del Lavoro, 1/2013.

Micheli, G. A., L'onere della prova, (ed. Cedam) Padova, 1966.

Militello, M., "Il laboratorio Fiat. La tutela della Fiom tra diritto sindacale e diritto antidiscriminatorio (Nota a App. Roma, ord. 19 ottobre 2012, App. Potenza 23 marzo 2012 e Trib. Roma, ord. 21 giugno 2012)", Foro Italiano, 1/2013.

Morozzo Della Rocca, P., "Gli atti discriminatori e lo straniero nel diritto civile", Principio di uguaglianza e divieto di compiere atti discriminatori, (Ed. ESI) Napoli, 2002.

Pacillo, V., "Il divieto di discriminazione religiosa nel rapporto di lavoro subordinato", www.olir.it, 2004.

Pacillo, V., "Libertà di religione, luoghi di culto e simboli religiosi. Prospettive generali", Veritas et Jus, 8/2014.

Palomino Lozano, R., Religión y derecho comparado, (Ed. Iustel) Madrid, 2007.

Ormazabal Sánchez, G., "Discriminación y carga de la prueba en el proceso civil", (Ed. Marcial Pons) Madrid, 2011.

Ranieri, M., "Da Philadelphia a Taormina: dichiarazioni omofobiche e tutela antidiscriminatoria", Rivista Italiana Diritto Lavoro, 1/2015.

Scarselli, G., "Appunti sulla discriminazione razziale e la sua tutela giurisdizionale", Rivista Diritto Civile, 6/2001.

Silvestri, G., "La religione nello spazio pubblico. Leggere la costituzione in un'Italia multiculturale", Aggiornamenti sociali, 3/2015.

Taruffo, M., "La valutazione delle prove", La prova nel processo civile (a cura M. Taruffo), (ed. Giuffrè) Milano, 2012.

Taruffo, M., "Note sull'esecuzione degli obblighi di fare e di non fare", Giurisprudenza Italiana, 3/2014.

Verde, G., L'onere della prova nel processo civile, (ed. Jovene) Napoli, 1974.

Vickers, L., "Religion and belief Discrimination in Employment", The EU law, European Commission, November 2006.

Virgadamo, P., Danno non patrimoniale e "ingiustizia conformata", (Giappichelli), Torino, 2014. 